\title{
Mengukur transparansi pengelolaan keuangan daerah di Indonesia: berbasis website
}

\author{
Irwan Taufiq Ritonga ${ }^{1 *}$, Syamsul ${ }^{2}$ \\ ${ }^{1}$ Fakultas Ekonomika dan Bisnis, Universitas Gajah Mada, Yogyakarta, Indonesia \\ ${ }^{*}$ Corresponding Author E-mail: abangupi@yahoo.com \\ ${ }^{2}$ Sekolah Tinggi Ilmu Ekonomi Panca Bhakti Palu, Sulawesi Tengah, Indonesia \\ E-mail: syamsulsyahrir@gmail.com
}

\section{A R T I K E L I N F O}

\section{Article history:}

Available online 1 December 2016

\section{Keywords:}

Transparency of local financial management, provincial government website.

\section{A B S T R A C T}

This study aims to measure the transparency of local financial management in Indonesia by focusing on three main stages (aspects) of local financial management, namely the aspects of planning, implementation, and reporting and accountability of the budget.This research was conducted in 34 provincial governmentsin Indonesia.The data used is the local financial management of the fiscal year 2016.Based on observations, it was found that the average level of local transparency managementis still very small (low), which is equal to $16.84 \%$..

\begin{abstract}
A B S T R A K
Penelitian ini bertujuan untuk mengukur transparansi pengelolaan keuangan daerah di Indonesia dengan berfokus pada tiga tahapan utama (aspek) pengelolaan keuangan daerah, yaitu aspek perencanaan, pelaksanaan, dan pelaporan dan pertanggungjawaban APBD. Penelitian ini dilakukan pada 34 pemerintah provinsi (pemprov) di Indonesia. Data yang digunakan adalah data pengelolaan keuangan daerah tahun anggaran 2016. Berdasarkan hasil pengamatan, ditemukan bahwa rata-rata tingkat transparansi pengelolaan daerah masih sangat sedikit (rendah), yakni sebesar 16,84\%.
\end{abstract}

\section{Pendahuluan}

Sejak ditetapkannya Undang-Undang (UU) No. 14 Tahun 2008 tentang Keterbukaan Informasi Publik yang menyatakan bahwa seluruh badan publik, termasuk pemerintah daerah (pemda), berkewajiban menerbitkan informasi publik atas setiap aktivitas yang dilaksanakannya. Regulasi ini, kemudian ditindaklanjuti dengan diterbitkannya Instruksi Menteri Dalam Negeri (Mendagri) No. 188.52/1797/SJ/2012 tentang Transparansi Pengelolaan Anggaran Daerah (TPAD). Instruksi Mendagri tersebut mengamanatkan pemda untuk menyiapkan menu content dengan nama TPAD dalam website resmi pemda.Selanjutnya, kembali dipertegas dengan dikeluarkannya Instruksi Presiden (Inpres) No. 07 Tahun 2015 tentang Aksi Pencegahan dan Pemberantasan Korupsi. Diterbitkannya beberapa peraturan tersebut adalah sebagai bentuk komitmen pemerintah untuk menciptakan penyelenggaraan pemerintahan yang bersih dan transparan. Lebih lanjut,poin 32 lampiran Inpres tersebut menginstruksikan kepadaseluruh pemda (provinsi, kabupaten, dan kota) untuk meningkatkan transparansi pengelolaan keuangan daerah. Hal ini penting, mengingat bahwa pengelolaan keuangan daerah adalah subsistem dari sistem pengelolaan keuangan negara dan merupakan elemen pokok dalam penyelenggaraan pemerintahan daerah (Peraturan Pemerintah (PP) No. 58 Tahun 2005 tentang Pengelolaan Keuangan Daerah).

Beberapa penelitian sebelumnya (lihat, Hermana et al. 2012; Sofia dan Husen 2013; Martani, Fitriasari, dan Annisa 2014) telah berusaha mengukur perkembangan transparansi pengelolaan keuangan daerah di Indonesia. Pertama, penelitian Hermana et al. (2012)menggunakan data website pada 33 pemerintah provinsi, 349 pemerintah kabupaten, dan 91 pemerintah kota di Indonesia. Data dikumpulkan pada bulan Juni 2011. Hasil analisis menunjukkan rata-rata indeks nasional untuk informasi keuangan sebesar 19,1\%. Mereka juga menunjukkan bahwa rata-rata indeks pengungkapan informasi keuangan dan non-keuangan untuk pemerintah kota lebih tinggi dibanding dengan pemerintah provinsi dan kabupaten. Selain itu, temuan lainnya adalah adanya 
indikasi kesenjangan digital antara tingkat pemda dan antara daerah di Pulau Jawa dengan daerah di luar Jawa. Kedua, Sofia dan Husen (2013) meneliti informasi keuangan dan non-keuangan yang diungkapkan oleh 350 pemda (kabupaten dan kota) di website resmi masing-masing pemda. Pengumpulan data dilakukan selama bulan April 2012. Mereka menunjukkan bahwa rata-rata pengungkapan informasi keuangan di websitepemda hanya sebesar 9,9\%. Sementara itu, untuk informasi non-keuangan lebih tinggi dibanding dengan informasi keuangan, yakni memiliki indeks rata-rata sebesar 59,1\%. Ketiga, Martani et al.(2014) mengukur pengungkapan transparansi keuangan dan kinerja pemda pada 490 kota/kabupaten di Indonesia. Data yang digunakan adalah 429 data website pemda yang dapat diakses dan diamati dari pertengahan Mei sampai dengan Juli 2013. Pengukuran tersebut terdiri dari lima besar indikator, yaitu berita keuangan, APBD, Laporan Keuangan, Laporan Kinerja, dan Daerah dalam Angka. Temuan mereka menginformasikan bahwa tingkat transparansi informasi keuangan dan kinerja pemda mencapai 15\%. Selain itu, mereka juga menunjukkan bahwa pemdapaling banyak mengungkapkan informasi keuangan dan kinerja dalam bentuk berita dan informasi Pemda Dalam Angka. Sementaraitu, untuk informasi utama keuangan dan kinerja yang berupa APBD, laporan keuangan dan laporan kinerja pengungkapannya masihdi bawah $10 \%$.

Singkatnya, penelitian di atas (lihat, Hermana et al. 2012; Sofia dan Husen 2013; Martani et al. 2014) secara umum memberikan informasi bahwa tingkat transparansi pengelolaan keuangan daerah masih rendah. Namun demikian, penelitian tersebut dalam mengukur transparansi informasi pengelolaan keuangan daerah hanya terbatas pada informasi yang terkait dengan aspek pelaporan dan pertanggung jawaban keuangan daerah. Penelitian tersebut tidak mencakup seluruh aspek pengelolaan keuangan daerah. Akhirnya, informasi yang diberikan dari pengukuran tersebut tidak memadai untuk dijadikan dasar dalam pengambilan keputusan.

Selanjutnya, keterbatasan lain dari penelitian tersebut adalah terbatas pada dua kriteria informasi, yaitu ketersediaan dan aksesibilitas dalam mengukur transparansi informasi pengelolaan keuangan daerah. Dengan kata lain penelitian terdahulu belum mempertimbangkan ketepatan waktu pengungkapan informasi pengelolaan keuangan daerah. Padahal, esensi sebenarnya atau sejatinya dari sebuah informasi terletak pada ketepatan waktu pengungkapan (publikasi). Armstrong (2005); Chalid Pheni (2005); dan Fung (2014) menyatakan bahwa ketepatan waktu adalah salah satu pilar utama dari transparansi. Hal ini dikarenakan informasi yang disajikan tepat waktu, tentunya akan memiliki nilai sempurna, lebih bermanfaat, dan lebih berpengaruh bagi pengambilan keputusan. Dalam hal ini informasi yang tepat waktu dapat digunakan oleh pemangku kepentingan (publik) misalnya, untuk mengawasi dan mengkritisi kebijakan pengelolaan keuangan daerah. Oleh karena itu, tujuan dari penelitian ini selain untuk mengukur perkembangan transparansi pengelolaan keuangan daerah, tetapi juga untuk menutupi keterbatasan penelitian sebelumnya dalam mengukur transparansi pengelolaan keuangan daerah. Dengan mengukur masing-masing tahapan pengelolaan keuangan daerah yang didasarkan pada tiga kriteria utama informasi, yakni ketersediaan, aksesibilitas, dan ketepatan waktu pengungkapan. Lebih dari itu, temuan penelitian diharapkan memberikan kontribusi yang bermanfaat bagi pemerintah dalam menunjukkan tingkat transparansi pengelolaan keuangan daerah. Dengan demikian, hasil penelitian ini dapat dijadikan bahan evaluasi atas pelaksanaan transparansi pengelolaan keuangan daerah.

\section{Tinjuan Pustaka dan Perumusan Hipotesis}

\section{Konsep Transparansi Pengelolaan Keuangan Daerah}

Transparansi adalah sebuah konsep yang luas berhubungan dengan ketersediaan informasi (supply side of transparency), dapat diakses, dan digunakan oleh masyarakat dan pemangku kepentingan lainnya (demand side of transparancy) (Araujo dan Tejedo-Romero 2016). Hal ini didasarkan pada ketersediaan informasi organisasi pemerintah yang memungkinkan warga negara dan aktor eksternal lainnya untuk memantau dan menilai kinerja internal dan kinerja organisasi publik (Meijer 2013; Grimmelikhuijsen 2012). Transparansi adalah sarana untuk meningkatkan efektivitas kebijakan, administrasi dan manajerial (Hirsch dan Osborne 2000). Silver (2005) kemudian diikuti Ridha dan Basuki (2012) mendefinisikan transparansi sebagai suatu kejujuran dan ketepatan yang tidak hanya dalam jumlah yang disampaikan atau dirilis oleh organisasi, tetapi juga bagaimana organisasi menjalankan operasionalnya. Transparansi mengacu pada akses yang tidak terbatas oleh masyarakat untuk informasi yang tepat waktu dan dapat diandalkan pada keputusan dan kinerja di sektor publik (Armstrong 2005).

Dalam konteks pemerintah daerah (pemda), Mardiasmo (2004) menyatakan bahwa transparansi berarti keterbukaan (openness) pemerintah dalam memberikan informasi yang terkait dengan aktivitas pengelolaan sumber daya publik kepada pihak-pihak yang membutuhkan informasi (Mardiasmo 2004). Lebih lanjut, transparansi pengelolaan keuangan daerah adalah keterbukaan pemda membuat kebijakan-kebijakan keuangan daerah sehingga dapat diketahui dan diawasi oleh DPRD dan masyarakat. Menurut Mardiasmo (2004) transparansi pengelolaan keuangan daerah pada akhirnya akan menciptakan horizontal accountability antara 
pemerintah daerah dengan masyarakatnya sehingga tercipta pemerintahan daerah yang bersih, efektif, efisien, akuntabel, dan responsif terhadap aspirasi dan kepentingan masyarakat.

Chalid (2005) menyatakan bahwa transparansi berarti pemerintah terbuka dalam memberikan informasi yang seluas-luasnya dalam pengelolaan sumber daya publik kepada masyarakat. Dalam hal pengelolaan keuangan yang pada dasarnya merupakan dana masyarakat, maka pemerintah perlu didorong untuk memberikan informasi keuangan yang diperlukan secara akurat, relevan, tepat waktu dan dapat dipercaya (Chalid 2005). Mulai dari proses perencanaan hingga pertanggungjawaban atas program dan anggaran yang telah ditetapkan.

Sebelumnya, Mardiasmo (2002) juga menyatakan bahwa transparansi merupakan prinsip yang harus dipegang teguh dan dilaksanakan dalam pengelolaan keuangan daerah. Hal ini karena pada dasarnya masyarakat (publik) memiliki hak dasar terhadap pemda, yaitu:

1) hak untuk mengetahui (right to know) yaitu: mengetahui kebijakan pemerintah, mengetahui keputusan yang diambil pemerintah, dan mengetahui alasan yang dilakukannya suatu kebijakan dan keputusan tertentu.

2) hak untuk diberi informasi (right to informed) yang meliputi hak untuk diberi penjelasan secara terbuka atas permasalahan-permasalahan yang menjadi perdebatan publik.

3) hak untuk didengar aspirasinya (right to be heard and to listened to).

Dari beberapa argumentasi tersebut di atas, dapat disimpulkan bahwa transparansi tidak hanya sebatas ketersediaan informasi dan informasi tersebut dapat di akses oleh publik, namun juga disajikan (dipublikasikan) dengan tepat waktu. Informasi yang dipublikasikan dengan tepat waktu tentunya akan lebih bermanfaat dan berpengaruh dalam pengambilan keputusan publik terkait dengan penyelenggaraan pemerintahan, khususnya yang berhubungan dengan pengelolaan keuangan daerah.

\section{Lingkup Pengelolaan Keuangan Daerah}

Bentuk anggaran publik dinyatakan dalam bentuk Anggaran Pendapatan dan Belanja Negara/Daerah (APBN/D). APBN/D adalah alat utama pemerintah untuk menyejahterakan rakyatnya dan sekaligus sebagai alat pemerintah untuk mengelola keuangan publik (negara/daerah). Merujuk pada Peraturan Pemerintah (PP) No. 58 Tahun 2005 tentang Pengelolaan Keuangan Daerah dan Peraturan Menteri Dalam Negeri (Permendagri) No. 13 Tahun 2006 tentang Pedoman Pengelolaan Keuangan Daerah, pengelolaan keuangan daerah adalah keseluruhan kegiatan yang meliputi perencanaan, pelaksanaan, penatausahaan, pelaporan, pertanggungjawaban, dan pengawasan keuangan daerah. Berikut ini adalah penjelasan singkat dari setiap tahap pengelolaan keuangan daerah di Indonesia.

\section{Tahap Perencanaan}

Tahap ini proses penyusunan APBD mengacu pada Rencana Pembangunan Jangka Menengah Daerah (RPJMD). RPJMD yang telah disusun sebelumnya, menjadi dasar bagi pemerintah daerah (pemda) menyusun Rencana Kerja Pemerintah Daerah (RKPD). Setelah RKPD ditetapkan, selanjutnya pemda dalam hal ini kepala daerah menyusun rancangan Kebijakan Umum APBD (KUA). BerdasarkanKUA, pemda dan DPRD membahas rancangan Prioritas dan Plafon Anggaran Sementara (PPAS) yang disampaikan oleh kepala daerah. KUA dan PPAS yang telah dibahas dan disepakati bersama antara kepala daerah dan DPRD dituangkan dalam nota kesepakatan yang ditandatangani bersama oleh kepala daerah dan pimpinan DPRD. Selanjutnya, atas dasar nota kesepakatan tersebut, kepala daerah menerbitkan pedoman penyusunan Rencana Kerja Anggaran-Satuan Kerja Perangkat Daerah (RKA-SKPD) sebagai pedoman kepala SKPD menyusun RKA-SKPD.

RKA-SKPD yang telah ditelaah oleh tim anggaran pemda, dijadikan pendoman oleh Pejabat Pengelola Keuangan Daerah (PPKD) dalam menyusun rancangan peraturan daerah (perda) tentang APBD dan dokumen pendukung yang terdiri dari nota keuangan dan rancangan APBD. Rancangan perda tentang APBD yang ditelah disusun selanjutnya kepala daerah menyampaikannya kepada DPRD disertai penjelasan dan dokumen pendukung untuk dibahas dalam rangka memperoleh persetujuan bersama. Atas dasar persetujuan bersama tersebut, selanjutnya kepala daerah menyiapkan rancangan peraturan kepala daerah tentang penjabaran APBD. Rancangan perda tentang APBD dan rancangan peraturan kepala daerah tentang penjabaran APBD, kemudian diserahkan kepada Gubernur dan Menteri Dalam Negeri untuk dievaluasi. Dari hasil evaluasi yang dilakukan oleh Gubernur dan Menteri Dalam Negeri, rancangan perda tentang APBD dan rancangan peraturan kepala daerah tentang penjabaran APBD ditetapkan oleh kepala daerah menjadi perda tentang APBD dan peraturan kepala daerah tentang penjabaran APBD. 


\section{Tahap Pelaksanaan}

Setelah APBD ditetapkan sebagai perda, selanjutnya PPKD memberitahukan kepada semua kepala SKPD agar menyusun dan menyampaikan rancangan Dokumen Pelaksanaan Anggaran SKPD (DPA-SKPD). Rancangan DPASKPD merinci sasaran yang hendak dicapai, fungsi, program, kegiatan, anggaran yang telah disediakan untuk mencapai sasaran tersebut, dan rencana penarikan dana tiap-tiap satuan kerja serta pendapatan yang diperkirakan. Rancangan DPA-SKPD yang telah disusun kepala SKPD, selanjutnya diserahkan kepada PPKD. Rancangan DPA-SKPD tersebut kemudian diverifikasi oleh tim anggaran pemda bersama-sama dengan kepala SKPD. Berdasarkan hasil verifikasi, PPKD mengesahkan rancangan DPA-SKPD dengan persetujuan sekretaris daerah. DPA-SKPD digunakan sebagai dasar pelaksanaan anggaran oleh kepala SKPD selaku pengguna anggaran/barang.

\section{Tahap Penatausahaan}

Pada tahap penata usahaan, dinyatakan bahwa pengguna anggaran/kuasa pengguna anggaran, bendahara penerimaan/pengeluaran dan orang atau badan yang menerima atau menguasai uang/barang/kekayaan daerah, wajib menyelenggarakan penatausahaan sesuai dengan peraturan perundang-undangan. Bendahara penerimaan dan/atau bendahara pengeluaran dalam melaksanakan tugas-tugas kebendaharaan pada satuan kerja dalam SKPD dibantu oleh pembantu bendahara penerimaan dan/atau pembantu bendahara pengeluaran sesuai kebutuhan dengan keputusan kepala SKPD. Dalam rangka manajemen kas daerah, PPKD menerbitkan Surat Pencairan Dana (SPD) dengan mempertimbangkan penjadwalan pembayaran pelaksanaan program dan kegiatan yang dimuat dalam DPA-SKPD.

\section{Tahap Pelaporan dan Pertanggungjawaban}

Pada tahap ini, kepala SKPD selaku pengguna anggaran menyelenggarakan akuntansi atas transaksi keuangan, aset, utang, dan ekuitas dana, yang berada dalam tanggung jawabnya. Penyelenggaraan akuntansi merupakan pencatatan/penatausahaan atas transaksi keuangan di lingkungan SKPD dan menyiapkan laporan keuangan sehubungan dengan pelaksanaan anggaran dan barang yang dikelolanya. Laporan keuangan yang disiapkan terdiri dari laporan realisasi anggaran, neraca, dan catatan atas laporan keuangan yang disampaikan kepada kepala daerah melalui PPKD. Kepala SKPD juga melampirkan surat pernyataan bahwa pengelolaan APBD yang menjadi tanggung jawabnya telah diselenggarakan berdasarkan sistem pengendalian intern yang memadai sesuai dengan ketentuan perundang-undangan.

PPKD menyelenggarakan akuntansi atas transaksi keuangan, aset, utang, ekuitas dana, termasuk transaksi pembiayaan dan perhitungannya. PPKD menyusun laporan keuangan pemda terdiri dari; laporan realisasi anggaran, neraca, laporan arus kas, dan catatan atas laporan keuangan. Laporan keuangan disusun dan disajikan sesuai dengan Peraturan Pemerintah tentang Standar Akuntansi Pemerintah dan didasarkan pada laporan keuangan SKPD. Laporan keuangan disertai dengan laporan ikhtisar realisasi kinerja dan laporan keuangan badan usaha milik daerah/perusahaan daerah. Laporan keuangan tersebut selanjutnya disampaikan kepada kepala daerah dalam rangka memenuhi pertanggungjawaban pelaksaan APBD. Kepala daerah menyampaikan rancangan perda tentang pertanggungjawaban pelaksanaan APBD kepada DPRD berupa laporan keuangan yang telah diperiksa oleh Badan Pemeriksa Keuangan (BPK) paling lambat 6 (enam) bulan setelah tahun anggaran berakhir.

\section{Tahap Pengawasan}

Tahap pengawasan keuangan daerah meliputi pembinaan dan pengawasan, pengendalian intern, dan pengendalian ekstern. Pembinaan dan pengawasan pengeloaan keuangan daerah dilakukan oleh pemerintah kepada pemda yang dikoordinasikan oleh Menteri Dalam Negeri. Pembinaan meliputi pemberian pedoman, bimbingan, supervisi, konsultasi, pendidikan, pelatihan, serta penelitian dan pengembangan. Sementara itu, pengawasan dilakukan oleh DPRD terhadap pelaksanaan perda tentang APBD. Tujuan pengawasan yang dilakukan DPRD adalah untuk menjamin pencapaian sasaran yang telah ditetapkan dalam perda tentang APBD.

\section{Indeks Keterbukaan Informasi Berdasarkan Open Budget Survey yang Dikeluarkan International Budget Partnership 2015}

International Budget Partnership (IBP) adalah sebuah lembaga independen internasional yang melakukan survei keterbukaan anggaran yang disebut Open Budget Survey (OBI). Survei ini dilakukan untuk mengukur keterbukaan informasi pengelolaan keuangan pemerintah negara-negara di seluruh dunia. Survei keterbukaan 
anggaran dilakukan dengan menggunakan bukti dokumen dan kriteria obyektif untuk mengevaluasi apakah pemerintah menyediakan kepada publik akses informasi yang komprehensif dan tepat waktu (Huwae 2016). Kategori keterbukaan informasi anggaran berdasarkan IBP (2015), dapat dilihat pada Tabel 1.

Tabel 1. Tingkat Kategori Keterbukaan Informasi Anggaran

\begin{tabular}{cllc}
\hline No. & Keterbukaan Anggaran & \multicolumn{1}{c}{ Kategori } & Skor \\
\hline 1. & Cukup (sufficient) & Ekstensif (extensive) & $81-100$ \\
& & Substansial (substantial) & $61-80$ \\
2. & Tidak cukup (insufficient) & Terbatas (limited) & $41-60$ \\
& & Minimal (minimal) & $21-40$ \\
& & Sedikit (scant or none) & $0-20$ \\
\hline
\end{tabular}

Sumber: lihat IBP (2015)

\section{Metoda Penelitian}

\section{Data}

Penelitian ini dilakukan di 34 pemerintah provinsi (pemprov) di Indonesia. Adapun alasan pemilihan pemprov sebagai objek penelitian adalah didasarkan pada Instruksi Mendagri No. 188.52/1797/SJ/2012. Instruksi tersebut ditujukan secara langsung kepada gubernur seluruh Indonesia dalam rangka pelaksanaan TPAD.Gubernur diberikan wewenang untuk menginstruksikan kepada Bupati/Walikota di wilayah masing-masing untuk mempublikasikan data mutahkir dalam menu content pengelolaan anggaran dan melakukan monitoring dan evaluasi atas instruksi tersebut.

Data pengelolaan keuangan daerah diperoleh dari masing-masing website resmi pemprov untuk tahun anggaran 2016. Data tersebut terdiri dari data perencanaan, pelaksanaan, dan pelaporan dan pertanggungjawaban pelaksanaan APBD. Lebih jelasnya, mengenai data tersebut dapat dilihat pada sub bagian berikutnya, yang menguraikan tentang definisi operasional dan pengukurannya. Selanjutnya, pengecekan dan pengambilan data tersebut, dilakukan mulai dari 1-31 November 2016 untuk periode pertama dan 1-10 Januari untuk periode kedua. Periode kedua dilakukan untuk mengecek kembali ketersediaan dalam website resmi pemprov. Hal ini didasarkan pada pengamatan peneliti dari beberapa pemprov untuk tahun sebelumnya, dokumen pengelolaan keuangan daerah diunggah setiap akhir periode anggaran berjalan hingga awal anggaran tahun berikutnya.

\section{Definisi Operasional dan Pengukuran}

Transparansi pengelolaan keuangan daerah didefinisikan sebagai suatu bentuk keterbukaan pemerintah dalam membuat kebijakan-kebijakan anggaran (keuangan) sehingga dapat diketahui dan diawasi oleh publik (masyarakat) dan pemangku kepentingan lainnya, mulai dari proses perencanaan, pelaksanaan, penatausahaan, pelaporan, pertanggungjawaban, dan pengawasan. Penelitian ini mengukur transparansi pengelolaan keuangan daerah didasarkan pada tiga tahapan utama pengelolaan keuangan daerah, yaitu (1) perencanaan; (2) pelaksanaan; dan (3) pelaporan dan pertanggungjawaban pelaksanaan APBD.

Masing-masing tahapan pengelolaan keuangan daerah diukur dengan menggunakan 3 (tiga) kriteria utama, yaitu ketersediaan, aksesibilitas, dan ketepatan waktu pengungkapan informasi pengelolaan keuangan daerah. Ketersediaan menunjukkan bahwa informasi pengelolaan keuangan daerah yang diukur tersedia di website resmi pemda. Tersedia, artinya informasi tersebut disediakan untuk umum (publik) di website resmi oleh pemprov. Aksesibilitas menunjukkan bahwa informasi yang tersedia tersebut dapat diunduh oleh publik. Artinya, informasi tersebut dapat dengan mudah diambil oleh publik tanpa harus melalui prosedur yang rumit. Sementara itu, ketepatan waktu pengungkapan didefinisikan sebagai informasi mengenai pengelolaan keuangan daerah disajikan (disediakan) di website resmi pemprovsesuai dengan rentang waktu yang dipersyaratkan (diharapkan).

Lebih lanjut, ketepatan waktu dinilai berdasarkan tanggal pemprov mengunggah informasi pengelolaan keuangan daerah dibandingkan dengan tanggal yang dipersyaratkan (diharapkan) peneliti. Dalam penelitian ini waktu yang dipersyaratkan adalah tiga puluh hari setelah dokumen pengelolaan keuangan daerah ditetapkan. Pengambilan keputusannya adalah apabila pemprov mempublikasikan informasi pengelolaan keuangan daerah pada rentang waktu yang dipersyaratkan, maka dinyatakan tepat waktu. Sebaliknya, apabila informasi pengelolaan keuangan daerah dipublikasikan melewati rentang waktu yang dipersyaratkan, maka dinyatakan tidak tepat waktu. Namun, untuk informasi yang sifatnya tersedia secara online atau setiap saat. Jenis informasi tersebut adalah informasi tentang realisasi anggaran pendapatan, belanja, pembiayaan daerah, dan rencana umum 
pengadaan. Penilaian ketepatan waktu didasarkan pada tanggal terakhir diperbaharui informasi yang ada dalam layanan elektronik tersebut, yakni maksimal telah diperbaharui satu bulan terakhir. Selengkapnya, dapat dilihat pada Lampiran 1 penelitian ini.

Instrumen transparansi pengelolaan keuangan daerah yang digunakan merupakan modifikasi dari instrumen penelitian Huwae (2016). Pemilihan instrumen Huwae (2016) didasarkan pada pertimbangan bahwa instrumen tersebut telah divalidasi oleh para ahli, baik dari kalangan akademisi maupun praktisi sektor publik (pemerintah). Dengan demikian, peneliti mengaggap bahwa instrumen tersebut telah tepat untuk digunakan dalam mengukur transparansi pengelolaan keuangan daerah. Modifikasi instrumen tersebut dengan menambahkan kriteria aksesibilitas, ketepatan waktu publikasi, dan perubahan tanggal dan tahun pengamatan pengelolaan keuangan daerah. Penilaian pada tahap perencanaan APBD terdiri dari 10 (sepuluh) indikator, tahap pelaksanaan APBD terdiri dari 9 (sembilan) indikator, dan tahap pelaporan dan pertanggungjawaban APBD terdiri dari 10 (sepuluh) indikator. Lebih jelasnya, dapat dilihat pada lampiran 2 penelitian ini yang menyajikan ringkasan poin-poin instrumen pengukuran transparansi pengelolaan keuangan daerah.

Adapun tata cara penentuan indeks transparansi pengelolaan keuangan daerah adalah sebagai berikut. Pertama, pengukuran menggunakan skor dikotomi, jika suatu item tersedia, dapat diakses, dan tepat waktu diberi nilai masing-masing 1 untuk setiap kriteria dan jika tidak tersedia, tidak dapat diakses (diunduh), dan tidak tepat waktu akan diberi nilai 0 . Kedua, skor yang diperoleh untuk kriteria ketersediaan dan aksesibilitas masing-masing dikalikan 0,25. Sementara itu, untuk kriteria ketepatan waktu pengungkapan dikalikan 0,5. Hasil perkalian tersebut, selanjutnya dijumlahkan untuk mendapatkan skor total untuk setiap indikator (item). Pemberian bobot 0,5 untuk kriteria ketepatan waktu pengungkapan lebih tinggi dibandingkan dengan kriteria ketersediaan dan aksesibilitas yang hanya diberikan bobot masing-masing 0,25. Alasannya adalah peneliti mengaggap bahwa ketepatan waktu pengungkapan adalah poin penting dan ruh dari sebuah informasi. Informasi yang tepat waktu mempunyai nilai yang lebih sempurna, lebih bermanfaat, dan lebih berpengaruh bagi pengambilan keputusan. Artinya, walaupun informasi itu tersedia dan dapat diakses, namun tidak disajikan dengan tepat waktu. Maka, informasi tersebut tidak dapat digunakan oleh publik atau para pemangku kepentingan dalam pengambilan keputusan. Dalam konteks ini, hanya informasi yang disajikan tepat waktu yang dapat digunakan oleh publik dalam melakukan pengawasan terhadap pengelolaan keuangan daerah. Ketiga, skor yang diperoleh setiap indikator dijumlahkan untuk mendapatkan skor total untuk setiap pemda. Keempat, menghitung tingkat transparansi dengan cara membagi total skor yang diperoleh dengan total skor yang diharapkan dapat diperoleh oleh setiap indikator, kemudian dikalikan seratus. Selengkapnya, dapat dilihat pada Lampiran 4 penelitian ini.

\section{Hasil dan Pembahasan}

\section{Analisis Transparansi Pengelolaan Keuangan Daerah}

Pengukuran transparansi pengelolaan keuangan daerah didasarkan pada tiga tahapan utama pengelolaan keuangan daerah, yaitu (1) perencanaan; (2) pelaksanaan; dan (3) pelaporan dan pertanggungjawaban pelaksanaan APBD. Berikut ini adalah hasil observasi website resmi pemda dan website yang berhubungan dengan publikasi pemda. Adapun daftar website pemda yang ditelusuri dapat dilihat pada Lampiran 3 penelitian ini.

\section{Aspek Perencanaan}

Hasil evaluasi indeks transparansi pengelolaan keuangan daerah, untuk aspek perencanaan dapat dilihat pada Tabel 2. Pada Tabel 2 menunjukkan bahwa Pemerintah Provinsi (Pemprov) Kalimantan Timur menduduki urutan tertinggi dalam pemenuhan indikator pada aspek perencanaan, yaitu dengan skor 6,5 dari skor maksimal 10 (65\%). Sementara itu, sembilan pemprov menempati urutan terendah yakni dengan skor 0 (0\%), yaitu Pemprov Riau, Pemprov Kepulauan Riau, Pemprov Kalimantan Barat, Pemprov Sulawesi Utara, Pemprov Sulawesi Selatan, Pemprov Sulawesi Tenggara, Pemprov Sulawesi Barat, Pemprov Maluku Utara, dan Pemprov Papua Barat.

Selanjutnya, pada Tabel 2 juga memperlihatkan bahwa indikator yang paling banyak dipenuhi oleh pemprov adalah indikator nomor 7, yakni informasi Peraturan Daerah tentang APBD, dengan rata-rata indeks sebesar 0,35. Selanjutnya, indikator yang paling sedikit dipenuhi adalah indikator nomor 2 dan 3, menyangkut informasi tentang Ringkasan Kebijakan Umum Anggaran dan Ringkasan Dokumen Prioritas dan Plafon Anggaran, dengan rata-rata indeks pemenuhan sebesar 0,04. Bahkan, Provinsi Kalimantan Timur yang memiliki indeks paling tinggi untuk aspek perencanaan juga tidak mempublikasikan informasi tersebut. 
Tabel 2. Aspek Perencanaan dalam Indeks Transparansi Pengelolaan Keuangan Daerah

\begin{tabular}{|c|c|c|c|c|c|c|c|c|c|c|c|c|}
\hline \multicolumn{13}{|c|}{ Tahap Perencanaan dan Penganggaran APBD } \\
\hline \multirow{2}{*}{ Nama Pemprov } & \multicolumn{10}{|c|}{ Indikator } & \multirow{2}{*}{ Total } & \multirow{2}{*}{ Indeks } \\
\hline & 1 & 2 & 3 & 4 & 5 & 6 & 7 & 8 & 9 & 10 & & \\
\hline Aceh & 0 & 0 & 0 & 0.5 & 0 & 0 & 0.5 & 0.5 & 0.5 & 0 & 2 & 20 \\
\hline Sumatera Utara & 0.5 & 0 & 0 & 0 & 0 & 0 & 0 & 0 & 0 & 0 & 0.5 & 5 \\
\hline Sumatera Barat & 0 & 0 & 0 & 1 & 1 & 1 & 1 & 0 & 1 & 0 & 5 & 50 \\
\hline Riau & 0 & 0 & 0 & 0 & 0 & 0 & 0 & 0 & 0 & 0 & 0 & 0 \\
\hline Jambi & 0.5 & 0 & 0 & 0 & 0 & 0.5 & 0 & 0 & 0 & 0 & 1 & 10 \\
\hline Sumatera Selatan & 1 & 0 & 0 & 0.5 & 0.5 & 0 & 0 & 0 & 0.5 & 0.5 & 3 & 30 \\
\hline Bengkulu & 0 & 0 & 0 & 0 & 0 & 0 & 0 & 0.5 & 0 & 0 & 0.5 & 5 \\
\hline Lampung & 0.5 & 0 & 0 & 0 & 0 & 0 & 0 & 0 & 0.5 & 0 & 1 & 10 \\
\hline Bangka Belitung & 0 & 0 & 0 & 0 & 0 & 0 & 0.5 & 0.5 & 0 & 0 & 1 & 10 \\
\hline Kepulauan Riau & 0 & 0 & 0 & 0 & 0 & 0 & 0 & 0 & 0 & 0 & 0 & 0 \\
\hline DKI Jakarta & 0.5 & 0.5 & 0.5 & 0 & 0 & 0.5 & 0.25 & 0 & 0 & 0 & 2.25 & 22.5 \\
\hline Jawa Barat & 0 & 0 & 0 & 0 & 0 & 0 & 1 & 0 & 1 & 1 & 3 & 30 \\
\hline Jawa Tengah & 0.5 & 0 & 0 & 0 & 0 & 1 & 1 & 1 & 1 & 1 & 5.5 & 55 \\
\hline D.I. Yogyakarta & 0.5 & 0 & 0 & 0.5 & 0 & 1 & 1 & 0 & 0 & 0 & 3 & 30 \\
\hline Jawa Timur & 0.5 & 0 & 0 & 0 & 0 & 0 & 0.5 & 0.5 & 0 & 0 & 1.5 & 15 \\
\hline Banten & 0 & 0 & 0 & 0.5 & 0.5 & 0 & 1 & 0.5 & 0.5 & 0.5 & 3.5 & 35 \\
\hline Bali & 0.5 & 0 & 0 & 0.5 & 0.25 & 0.5 & 0.25 & 0 & 1 & 1 & 4 & 40 \\
\hline Nusa Tenggara Barat & 0 & 0 & 0 & 0 & 0 & 0 & 1 & 0.5 & 0 & 0 & 1.5 & 15 \\
\hline Nusa Tenggara Timur & 0 & 0 & 0 & 0.5 & 0.5 & 0.5 & 0.5 & 0 & 0.5 & 0.5 & 3 & 30 \\
\hline Kalimantan Barat & 0 & 0 & 0 & 0 & 0 & 0 & 0 & 0 & 0 & 0 & 0 & 0 \\
\hline Kalimantan Tengah & 0 & 0 & 0 & 0.5 & 0.5 & 0.5 & 0.5 & 0.5 & 0.5 & 0.5 & 3.5 & 35 \\
\hline Kalimantan Selatan & 0 & 0 & 0 & 0.5 & 0 & 0.5 & 0.5 & 0.5 & 0.5 & 0.5 & 3 & 30 \\
\hline Kalimantan Timur & 0.5 & 0 & 0 & 1 & 1 & 0 & 1 & 1 & 1 & 1 & 6.5 & 65 \\
\hline Kalimantan Utara & 0 & 0 & 0 & 0 & 0 & 0 & 0.5 & 0.5 & 0 & 0 & 1 & 10 \\
\hline Sulawesi Utara & 0 & 0 & 0 & 0 & 0 & 0 & 0 & 0 & 0 & 0 & 0 & 0 \\
\hline Sulawesi Tengah & 0.5 & 0.5 & 0.5 & 0 & 0 & 0 & 0 & 0 & 0 & 0 & 1.5 & 15 \\
\hline Sulawesi Selatan & 0 & 0 & 0 & 0 & 0 & 0 & 0 & 0 & 0 & 0 & 0 & 0 \\
\hline Sulawesi Tenggara & 0 & 0 & 0 & 0 & 0 & 0 & 0 & 0 & 0 & 0 & 0 & 0 \\
\hline Gorontalo & 1 & 0 & 0 & 0.5 & 0.5 & 0.5 & 0.5 & 0 & 0.5 & 0.5 & 4 & 40 \\
\hline Sulawesi Barat & 0 & 0 & 0 & 0 & 0 & 0 & 0 & 0 & 0 & 0 & 0 & 0 \\
\hline Maluku & 0.5 & 0.5 & 0.5 & 0 & 0 & 0 & 0 & 0 & 0 & 0 & 1.5 & 15 \\
\hline Maluku Utara & 0 & 0 & 0 & 0 & 0 & 0 & 0 & 0 & 0 & 0 & 0 & 0 \\
\hline Papua & 0 & 0 & 0 & 0 & 0 & 0.5 & 0.5 & 0 & 0 & 0 & 1 & 10 \\
\hline Papua Barat & 0 & 0 & 0 & 0 & 0 & 0 & 0 & 0 & 0 & 0 & 0 & 0 \\
\hline Rata-rata & 0.22 & 0.04 & 0.04 & 0.19 & 0.14 & 0.21 & 0.35 & 0.19 & 0.26 & 0.21 & 1.86 & 18.60 \\
\hline
\end{tabular}

Keterangan: Daftar indikator 1-10 dapat dilihat pada Lampiran 2 penelitian ini.

\section{Aspek Pelaksanaan}

Pada Tabel 3 dapat dilihat bahwa Pemprov Jawa Tengah berada di urutan teratas dalam pemenuhan indikator pada aspek pelaksanaan, yaitu dengan skor 6 (66,67\%). Sementara itu, dua puluh enampemprov berada di urutan terbawah, yakni dengan skor 1 (11,11\%). Pemprov tersebut adalah Pemprov Aceh, Pemprov Sumatera Utara, Pemprov Sumatera Barat, Pemprov Jambi, Pemprov Sumatera Selatan, Pemprov Lampung, Pemprov Kalimantan Utara, Pemprov Bangka Belitung, Pemprov Kepulauan Riau, Pemprov Jawa Barat, Pemprov D.I. Yogyakarta, Pemprov Jawa Timur, Pemprov Banten, Pemprov Bali, Pemprov Nusa Tenggara Timur, Pemprov Kalimantan Barat, Pemprov Sulawesi Utara, Pemprov Sulawesi Tenggara, Pemprov Sulawesi Tengah, Pemprov Sulawesi Selatan, Pemprov Sulawesi Barat, Pemprov Maluku, Pemprov Maluku Utara, Pemprov Papua, dan Pemprov Papua Barat.

Selain itu, Tabel 3 juga menunjukkan bahwa indikator yang paling banyak dipenuhi oleh pemprov adalah indikator nomor 8, yakni informasitentang Rencana Umum Pengadaan dengan rata-rata indeks sebesar 
1,00. Nilai tersebut menunjukkan bahwa seluruh pemprov menyajikan informasi tentang Rencana Umum Pengadaan. Selanjutnya, indikator yang paling sedikit dipenuhi denganrata-rata indeks pemenuhan sebesar 0,04 adalah indikator nomor 3, 7, dan 9, yakni informasi tentangRealisasi Pembiayaan Daerah, Ringkasan RKA Perubahan APBD, dan SK Kepala Daerah tentang Pejabat Pengelola Keuangan Daerah.

Tabel 3. Aspek Pelaksanaan dalam Indeks Transparansi Pengelolaan Keuangan Daerah

\begin{tabular}{|c|c|c|c|c|c|c|c|c|c|c|c|}
\hline \multicolumn{12}{|c|}{ Tahap Pelaksanaan APBD } \\
\hline \multirow{2}{*}{ Nama Pemprov } & \multicolumn{9}{|c|}{ Indikator } & \multirow{2}{*}{ Total } & \multirow{2}{*}{ Indeks } \\
\hline & 1 & 2 & 3 & 4 & 5 & 6 & 7 & 8 & 9 & & \\
\hline Aceh & 0 & 0 & 0 & 0 & 0 & 0 & 0 & 1 & 0 & 1 & 11.11 \\
\hline Sumatera Utara & 0 & 0 & 0 & 0 & 0 & 0 & 0 & 1 & 0 & 1 & 11.11 \\
\hline Sumatera Barat & 0 & 0 & 0 & 0 & 0 & 0 & 0 & 1 & 0 & 1 & 11.11 \\
\hline Riau & 0 & 0 & 0 & 0 & 1 & 0 & 0 & 1 & 0.5 & 2.5 & 27.78 \\
\hline Jambi & 0 & 0 & 0 & 0 & 0 & 0 & 0 & 1 & 0 & 1 & 11.11 \\
\hline Sumatera Selatan & 0 & 0 & 0 & 0 & 0 & 0 & 0 & 1 & 0 & 1 & 11.11 \\
\hline Bengkulu & 0 & 0 & 0 & 0 & 0 & 0 & 0 & 1 & 0.5 & 1.5 & 16.67 \\
\hline Lampung & 0 & 0 & 0 & 0 & 0 & 0 & 0 & 1 & 0 & 1 & 11.11 \\
\hline Bangka Belitung & 0 & 0 & 0 & 0 & 0 & 0 & 0 & 1 & 0 & 1 & 11.11 \\
\hline Kepulauan Riau & 0 & 0 & 0 & 0 & 0 & 0 & 0 & 1 & 0 & 1 & 11.11 \\
\hline DKI Jakarta & 1 & 1 & 1 & 0.25 & 0 & 0 & 0 & 1 & 0 & 4.25 & 47.22 \\
\hline Jawa Barat & 0 & 0 & 0 & 0 & 0 & 0 & 0 & 1 & 0 & 1 & 11.11 \\
\hline Jawa Tengah & 1 & 1 & 0 & 1 & 1 & 1 & 0 & 1 & 0 & 6 & 66.67 \\
\hline D.I. Yogyakarta & 0 & 0 & 0 & 0 & 0 & 0 & 0 & 1 & 0 & 1 & 11.11 \\
\hline Jawa Timur & 0 & 0 & 0 & 0 & 0 & 0 & 0 & 1 & 0 & 1 & 11.11 \\
\hline Banten & 0 & 0 & 0 & 0 & 0 & 0 & 0 & 1 & 0 & 1 & 11.11 \\
\hline Bali & 0 & 0 & 0 & 0 & 0 & 0 & 0 & 1 & 0 & 1 & 11.11 \\
\hline Nusa Tenggara Barat & 0 & 0 & 0 & 0 & 0 & 1 & 0 & 1 & 0 & 2 & 22.22 \\
\hline Nusa Tenggara Timur & 0 & 0 & 0 & 0 & 0 & 0 & 0 & 1 & 0 & 1 & 11.11 \\
\hline Kalimantan Barat & 0 & 0 & 0 & 0 & 0 & 0 & 0 & 1 & 0 & 1 & 11.11 \\
\hline Kalimantan Tengah & 0 & 0 & 0 & 1 & 1 & 0.5 & 1 & 1 & 0 & 4.5 & 50.00 \\
\hline Kalimantan Selatan & 0 & 0 & 0 & 0 & 0 & 0 & 0 & 1 & 0 & 1 & 11.11 \\
\hline Kalimantan Timur & 0.5 & 0.5 & 0.5 & 0 & 1 & 0 & 0 & 1 & 0 & 3.5 & 38.89 \\
\hline Kalimantan Utara & 0 & 0 & 0 & 0 & 0 & 0 & 0 & 1 & 0 & 1 & 11.11 \\
\hline Sulawesi Utara & 0 & 0 & 0 & 0 & 0 & 0 & 0 & 1 & 0 & 1 & 11.11 \\
\hline Sulawesi Tengah & 0 & 0 & 0 & 0 & 0 & 0 & 0 & 1 & 0 & 1 & 11.11 \\
\hline Sulawesi Selatan & 0 & 0 & 0 & 0 & 0 & 0 & 0 & 1 & 0 & 1 & 11.11 \\
\hline Sulawesi Tenggara & 0 & 0 & 0 & 0 & 0 & 0 & 0 & 1 & 0 & 1 & 11.11 \\
\hline Gorontalo & 0 & 0 & 0 & 0.5 & 0.5 & 0 & 0.5 & 1 & 0.5 & 3 & 33.33 \\
\hline Sulawesi Barat & 0 & 0 & 0 & 0 & 0 & 0 & 0 & 1 & 0 & 1 & 11.11 \\
\hline Maluku & 0 & 0 & 0 & 0 & 0 & 0 & 0 & 1 & 0 & 1 & 11.11 \\
\hline Maluku Utara & 0 & 0 & 0 & 0 & 0 & 0 & 0 & 1 & 0 & 1 & 11.11 \\
\hline Papua & 0 & 0 & 0 & 0 & 0 & 0 & 0 & 1 & 0 & 1 & 11.11 \\
\hline Papua Barat & 0 & 0 & 0 & 0 & 0 & 0 & 0 & 1 & 0 & 1 & 11.11 \\
\hline Rata-rata & 0.07 & 0.07 & 0.04 & 0.08 & 0.13 & 0.07 & 0.04 & 1.00 & 0.04 & 1.57 & 17.40 \\
\hline
\end{tabular}

Keterangan: Daftar indikator 1-9 dapat dilihat pada Lampiran 2 penelitian ini.

\section{Aspek Pelaporan dan Pertanggungjawaban}

Hasil evaluasi aspek pelaporan dan pertanggungjawaban transparansi pengelolaan keuangan daerah dapat dilihat pada Tabel 4. Pada Tabel 4 tersebut menginformasikan bahwa terdapat dua pemprov, yaitu Pemprov Sumatera Selatan, dan Pemprov Kalimantan Tengah menempati posisi teratas dalam pemenuhan indikator pada aspek pelaporan dan pertanggungjawaban dengan skor 6 (60\%). Sementara itu, sepuluh pemprov menempati posisi terbawah dengan skor 0 (0\%), yaitu Pemprov Sumatera Barat, Pemprov Bangka Belitung, Pemprov Bali,Pemprov Nusa Tenggara Timur, Pemprov Sulawesi Tengah, Pemprov Sulawesi Tenggara, Pemprov Sulawesi Barat,Pemprov Maluku, Pemprov Maluku Utara, Pemprov Papua, dan Pemprov Papua Barat.

Lebih dari itu, Tabel 4 juga menunjukkan bahwa indikator yang paling banyak dipenuhi oleh pemprov adalah indikator nomor 1, yakni informasi Peraturan Kepala Daerah tentang Kebijakan Akuntansi dengan ratarata indeks sebesar 0,25. Selanjutnya, indikator nomor 7 yakni informasi tentang Laporan Keuangan BUMD/Perusahaan Daerah yang paling sedikit dipenuhi dengan rata-rata indeks pemenuhan sebesar 0,00. 
Tabel 4. Aspek Pelaporan dan Pertanggungjawaban dalam Indeks Transparansi Pengelolaan Keuangan Daerah

\begin{tabular}{|c|c|c|c|c|c|c|c|c|c|c|c|c|}
\hline \multicolumn{13}{|c|}{ Tahap Pelaporan dan Pertanggungjawaban APBD } \\
\hline \multirow{2}{*}{ Nama Pemprov } & \multicolumn{7}{|c|}{ Indikator } & \multicolumn{3}{|c|}{ Total } & \multicolumn{2}{|l|}{ Indeks } \\
\hline & 1 & 2 & 3 & 4 & 5 & 6 & 7 & 8 & 9 & 10 & & \\
\hline Aceh & 0.5 & 0.5 & 0 & 0.5 & 0.5 & 0 & 0 & 0.5 & 0 & 0 & 2.5 & 25 \\
\hline Sumatera Utara & 0 & 0 & 0 & 0 & 0 & 0 & 0 & 0.5 & 0 & 0 & 0.5 & 5 \\
\hline Sumatera Barat & 0 & 0 & 0 & 0 & 0 & 0 & 0 & 0 & 0 & 0 & 0 & 0 \\
\hline Riau & 0.5 & 0 & 0 & 0 & 0 & 0 & 0 & 0 & 0.5 & 0 & 1 & 10 \\
\hline Jambi & 0 & 0 & 0 & 0 & 0 & 0 & 0 & 1 & 0 & 0 & 1 & 10 \\
\hline Sumatera Selatan & 0 & 1 & 1 & 1 & 1 & 1 & 0 & 0 & 0 & 1 & 6 & 60 \\
\hline Bengkulu & 1 & 0 & 0 & 0 & 0 & 0 & 0 & 0 & 0.5 & 0 & 1.5 & 15 \\
\hline Lampung & 0 & 0 & 0 & 0 & 0 & 0 & 0 & 0.5 & 0 & 0 & 0.5 & 5 \\
\hline Bangka Belitung & 0 & 0 & 0 & 0 & 0 & 0 & 0 & 0 & 0 & 0 & 0 & 0 \\
\hline Kepulauan Riau & 0 & 0 & 0 & 0 & 0 & 0 & 0 & 0.5 & 0 & 0 & 0.5 & 5 \\
\hline DKI Jakarta & 1 & 0.5 & 0 & 0.5 & 0.5 & 0 & 0 & 0 & 0 & 0 & 2.5 & 25 \\
\hline Jawa Barat & 0.5 & 0 & 0 & 0 & 0 & 0 & 0 & 0 & 0 & 0 & 0.5 & 5 \\
\hline Jawa Tengah & 0.5 & 0.5 & 0.5 & 0.5 & 0.5 & 0.5 & 0 & 0 & 0 & 0 & 3 & 30 \\
\hline D.I. Yogyakarta & 0 & 0 & 1 & 1 & 0 & 0 & 0 & 0 & 0 & 0 & 2 & 20 \\
\hline Jawa Timur & 0.5 & 1 & 0 & 1 & 1 & 0 & 0 & 1 & 1 & 0 & 5.5 & 55 \\
\hline Banten & 1 & 1 & 1 & 0 & 0.5 & 0.5 & 0 & 0 & 0 & 1 & 5 & 50 \\
\hline Bali & 0 & 0 & 0 & 0 & 0 & 0 & 0 & 0 & 0 & 0 & & 0 \\
\hline Nusa Tenggara Barat & 0.5 & 0 & 0 & 0 & 0 & 0 & 0 & 0 & 0 & 0 & 0.5 & 5 \\
\hline Nusa Tenggara Timur & 0 & 0 & 0 & 0 & 0 & 0 & 0 & 0 & 0 & 0 & 0 & 0 \\
\hline Kalimantan Barat & 0.5 & 0.5 & 0 & 0.5 & 0.5 & 0.5 & 0 & 1 & 0 & 0 & 3.5 & 35 \\
\hline Kalimantan Tengah & 0 & 1 & 1 & 1 & 1 & 1 & 0 & 0 & 0.5 & 0.5 & 6 & 60 \\
\hline Kalimantan Selatan & 0 & 0 & 0 & 0 & 0 & 0 & 0 & 0.5 & 0 & 0.5 & 1 & 10 \\
\hline Kalimantan Timur & 0.5 & 0.5 & 0 & 0 & 0.5 & 0.5 & 0 & 0.5 & 0.5 & 0.5 & 3.5 & 35 \\
\hline Kalimantan Utara & 0 & 0 & 0 & 0 & 0 & 0 & 0 & 0.5 & 0 & 0 & 0.5 & 5 \\
\hline Sulawesi Utara & 0.5 & 0 & 0 & 0 & 0 & 0 & 0 & 0 & 0 & 0 & 0.5 & 5 \\
\hline Sulawesi Tengah & 0 & 0 & 0 & 0 & 0 & 0 & 0 & 0 & 0 & 0 & 0 & 0 \\
\hline Sulawesi Selatan & 0.5 & 0 & 0 & 0 & 0 & 0 & 0 & 0.5 & 0 & 0 & 1 & 10 \\
\hline Sulawesi Tenggara & 0 & 0 & 0 & 0 & 0 & 0 & 0 & 0 & 0 & 0 & 0 & 0 \\
\hline Gorontalo & 0.5 & 0 & 0 & 0 & 0 & 0 & 0 & 0 & 0.5 & 0 & 1 & 10 \\
\hline Sulawesi Barat & 0 & 0 & 0 & 0 & 0 & 0 & 0 & 0 & 0 & 0 & 0 & 0 \\
\hline Maluku & 0 & 0 & 0 & 0 & 0 & 0 & 0 & 0 & 0 & 0 & 0 & 0 \\
\hline Maluku Utara & 0 & 0 & 0 & 0 & 0 & 0 & 0 & 0 & 0 & 0 & 0 & 0 \\
\hline Papua & 0 & 0 & 0 & 0 & 0 & 0 & 0 & 0 & 0 & 0 & 0 & 0 \\
\hline Papua Barat & 0 & 0 & 0 & 0 & 0 & 0 & 0 & 0 & 0 & 0 & 0 & 0 \\
\hline Rata-rata & 0.25 & 0.19 & 0.13 & 0.18 & 0.18 & 0.12 & 0.00 & 0.21 & 0.10 & 0.10 & 1.46 & 14.56 \\
\hline
\end{tabular}

Keterangan: Daftar indikator 1-10 dapat dilihat pada Lampiran 2 penelitian ini.

Selanjutnya, Tabel 5 menunjukkan secara keseluruhan indeks transparansi pengelolaan keuangan daerah, khususnya pada tiga tahapan (aspek) utama pengelolaan keuangan daerah, yakni tahap perencanaan, pelaksanaan, dan pelaporan dan pertanggungjawaban pelaksanaan APBD.

Pada Tabel 5 juga ditunjukkan bahwa Pemprov Jawa Tengah memiliki indeks transparansi pengelolaan keuangan daerah tertinggi, yakni dengan skor 14,5 dari skor maksimal 29 (50\%). Sementara itu, Pemprov Sulawesi Tenggara, Pemprov Sulawesi Barat, Pemprov Maluku Utara, dan Pemprov Papua Barat memiliki indeks pengelolaan keuangan daerah terendah dengan skor 1 (3,45\%). Lebih jelasnya, mengenai tata cara pengukuran indeks transparansi secara komposit dapat dilihat pada lampiran 4 penelitian ini. Selain itu, Tabel 5 juga menunjukkan bahwa aspek yang paling banyak dipenuhi oleh tiga puluh dua pemprov yang ditelusuri adalah aspek perencanaan dengan rata-rata indeks sebesar 1,86. Aspek pelaporan dan pertanggungjawaban adalah aspek yang paling sedikit dipenuhi denganrata-rata indeks pemenuhan sebesar 1,46. Selanjutnya, pada Gambar 1 juga dapat dilihat bahwa terdapat tiga belas pemprov, berada di atas rata-rata indeks transparansi pengelolaan keuangan daerah dan dua puluh satu pemprov, berada di bawah rata-rata indeks transparansi pengelolaan keuangan daerah. 
Tabel 5. 34 Pemerintah Provinsi di Indonesia dalam Indeks Transparansi Pengelolaan Keuangan Daerah

\begin{tabular}{|c|c|c|c|c|c|}
\hline Provinsi & $\begin{array}{l}\text { Peren } \\
\text { canaan }\end{array}$ & $\begin{array}{c}\text { Pelak } \\
\text { sanaan }\end{array}$ & $\begin{array}{c}\text { Pelaporan dan } \\
\text { Pertanggungjawaban }\end{array}$ & Total & Indeks \\
\hline Aceh & 2 & 1 & 2.5 & 5.5 & 18.96552 \\
\hline Sumatera Utara & 0.5 & 1 & 0.5 & 2 & 6.896552 \\
\hline Sumatera Barat & 5 & 1 & 0 & 6 & 20.68966 \\
\hline Riau & 0 & 2.5 & 1 & 3.5 & 12.06897 \\
\hline Jambi & 1 & 1 & 1 & 3 & 10.34483 \\
\hline Sumatera Selatan & 3 & 1 & 6 & 10 & 34.48276 \\
\hline Bengkulu & 0.5 & 1.5 & 1.5 & 3.5 & 12.06897 \\
\hline Lampung & 1 & 1 & 0.5 & 2.5 & 8.62069 \\
\hline Bangka Belitung & 1 & 1 & 0 & 2 & 6.896552 \\
\hline Kepulauan Riau & 0 & 1 & 0.5 & 1.5 & 5.172414 \\
\hline DKI Jakarta & 2.25 & 4.25 & 2.5 & 9 & 31.03448 \\
\hline Jawa Barat & 3 & 1 & 0.5 & 4.5 & 15.51724 \\
\hline Jawa Tengah & 5.5 & 6 & 3 & 14.5 & 50 \\
\hline D.I. Yogyakarta & 3 & 1 & 2 & 6 & 20.68966 \\
\hline Jawa Timur & 1.5 & 1 & 5.5 & 8 & 27.58621 \\
\hline Banten & 3.5 & 1 & 5 & 9.5 & 32.75862 \\
\hline Bali & 4 & 1 & 0 & 5 & 17.24138 \\
\hline Nusa Tenggara Barat & 1.5 & 2 & 0.5 & 4 & 13.7931 \\
\hline Nusa Tenggara Timur & 3 & 1 & 0 & 4 & 13.7931 \\
\hline Kalimantan Barat & 0 & 1 & 3.5 & 4.5 & 15.51724 \\
\hline Kalimantan Tengah & 3.5 & 4.5 & 6 & 14 & 48.27586 \\
\hline Kalimantan Selatan & 3 & 1 & 1 & 5 & 17.24138 \\
\hline Kalimantan Timur & 6.5 & 3.5 & 3.5 & 13.5 & 46.55172 \\
\hline Kalimantan Utara & 1 & 1 & 0.5 & 2.5 & 8.62069 \\
\hline Sulawesi Utara & 0 & 1 & 0.5 & 1.5 & 5.172414 \\
\hline Sulawesi Tengah & 1.5 & 1 & 0 & 2.5 & 8.62069 \\
\hline Sulawesi Selatan & 0 & 1 & 1 & 2 & 6.896552 \\
\hline Sulawesi Tenggara & 0 & 1 & 0 & 1 & 3.448276 \\
\hline Gorontalo & 4 & 3 & 1 & 8 & 27.58621 \\
\hline Sulawesi Barat & 0 & 1 & 0 & 1 & 3.448276 \\
\hline Maluku & 1.5 & 1 & 0 & 2.5 & 8.62069 \\
\hline Maluku Utara & 0 & 1 & 0 & 1 & 3.448276 \\
\hline Papua & 1 & 1 & 0 & 2 & 6.896552 \\
\hline Papua Barat & 0 & 1 & 0 & 1 & 3.448276 \\
\hline Rata-rata & 1.860294 & 1.566176 & 1.455882 & 4.882353 & 16.8357 \\
\hline
\end{tabular}

Penelitian ini mengukur transparansi pengelolaan keuangan daerah dengan memasukkan kriteria ketepatan waktu pengungkapan informasi pengelolaan keuangan daerah. Berbeda dengan penelitian yang telah dilakukan sebelumnya, sebatas mengukur informasi transparansi pengelolaan keuangan daerah berdasarkan pada ketersediaan dan aksesibilitas. Dalam Tabel 6, dapat dilihat perbandingan antara memasukkan kriteria ketepatan waktu dan tanpa ketepatan waktu publikasi dalam pengukuran transparansi informasi pengelolaan keuangan daerah. Dari Tabel 6, terlihat bahwa indeks tertinggi ketika tanpa memasukkan kriteria ketepatan waktu dalam mengukur transparansi informasi pengelolaan keuangan daerah adalah sebesar 65,52\%. Namun, ketika mempertimbangkan ketepatan waktu publikasi, turun menjadi $50.00 \%$. Begitu pula, rata-rata indeks transparansi pengelolaan keuangan daerah, apabila tidak mempertimbangkan ketepatan waktu publikasi, maka diperoleh nilai rata-rata sebesar $23,73 \%$. Akan tetapi, ketika memasukkan kriteria ketepatan waktu publikasi dalam pengukuran transparansi pengelolaan keuangan daerah, nilai rata-rata indeks hanya sebesar 16,84\%. Selain itu, dari Tabel 6 juga terlihat bahwa apabila tidak mempertimbangkan ketepatan waktu pengungkapan informasi pengelolaan keuangan daerah, maka Pemprov DKI Jakarta dan Pemprov Gorontalo berada di peringkat 4 teratas. Sementara itu, apabila memperhitungkan ketepatan waktu publikasi yang menduduki peringkat ke-4 adalah Pemprov Sumatera Selatan. Oleh karena itu, dengan mempertimbangkan ketepatan waktu dalam mengukur transparansi informasi pengelolaan keuangan daerah akan menjadikan pengukuran lebih akurat. 


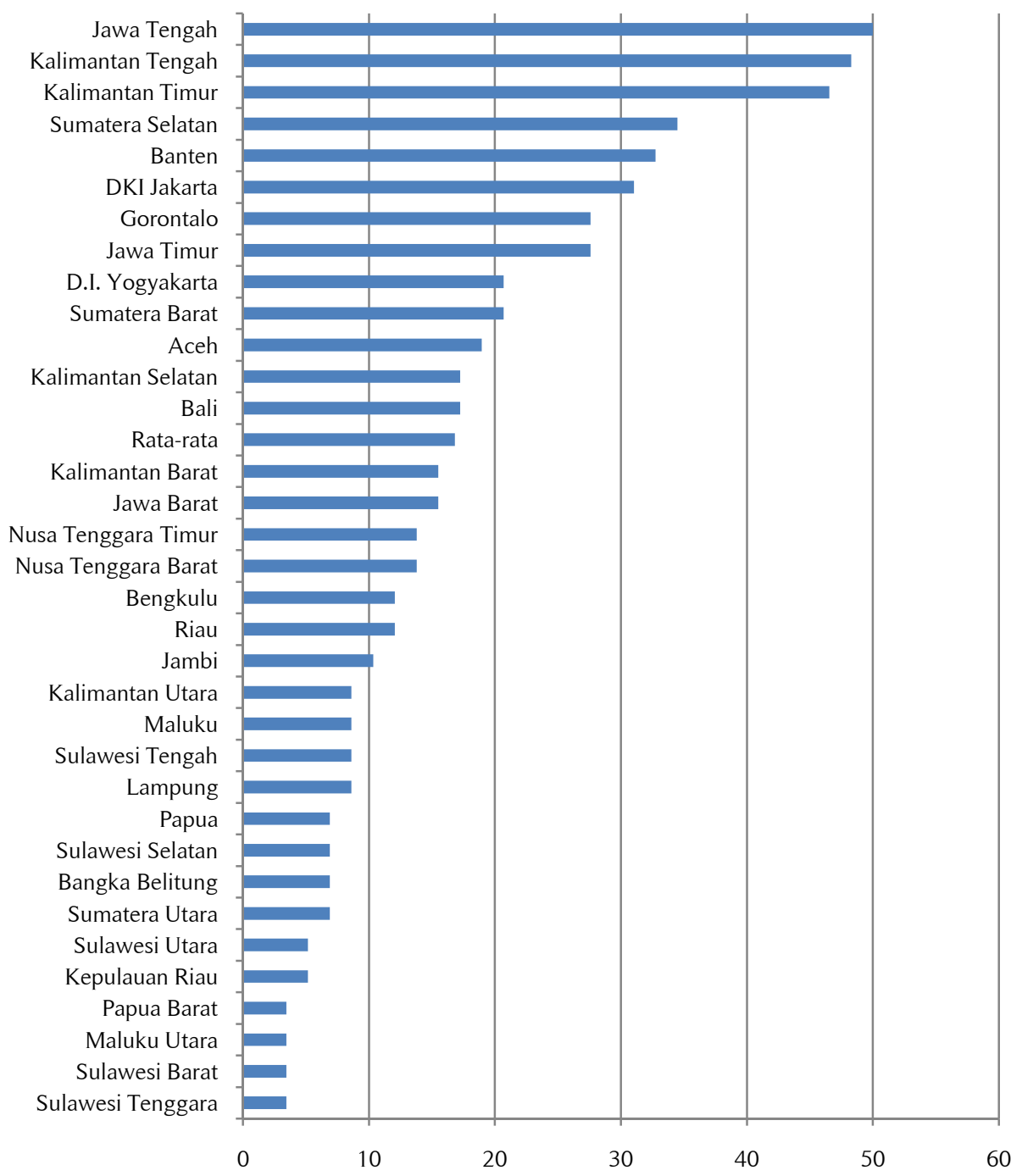

Gambar 1. Indeks Transparansi Pengelolaan Keuangan Daerah (34 Pemerintah Provinsi di Indonesia)

Tabel 6. Perbandingan Indeks Transparansi Pengelolaan Keuangan Daerah Tanpa Ketepatan Waktu dan Dengan Ketepatan Waktu

\begin{tabular}{clclc}
\hline Peringkat & \multicolumn{1}{c}{ Nama Pemprov } & $\begin{array}{c}\text { Tanpa } \\
\text { Tepat Waktu }\end{array}$ & \multicolumn{1}{c}{ Nama Pemda } & $\begin{array}{c}\text { Dengan } \\
\text { Tepat Waktu }\end{array}$ \\
\hline 1 & Jawa Tengah & 65.52 & Jawa Tengah & 50.00 \\
2 & Kalimantan Tengah & 65.52 & Kalimantan Tengah & 48.28 \\
3 & Kalimantan Timur & 65.52 & Kalimantan Timur & 46.55 \\
4 & DKI Jakarta & 48.28 & Sumatera Selatan & 34.48 \\
5 & Gorontalo & 48.28 & Banten & 32.76 \\
6 & Banten & 44.83 & DKI Jakarta & 31.03 \\
7 & Sumatera Selatan & 37.93 & Jawa Timur & 27.59 \\
8 & Aceh & 34.48 & Gorontalo & 27.59 \\
9 & Jawa Timur & 34.48 & Sumatera Barat & 20.69 \\
10 & Kalimantan Selatan & 31.03 & D.I. Yogyakarta & 20.69 \\
11 & Bali & 27.59 & Aceh & 18.97 \\
12 & D.I. Yogyakarta & 24.14 & Bali & 17.24 \\
13 & Nusa Tenggara Timur & 24.14 & Kalimantan Selatan & 17.24 \\
14 & Kalimantan Barat & 24.14 & Jawa Barat & 15.52 \\
15 & Sumatera Barat & 20.69 & Kalimantan Barat & 15.52 \\
16 & Riau & 17.24 & Nusa Tenggara Barat & 13.79 \\
17 & Bengkulu & 17.24 & Nusa Tenggara Timur & 13.79 \\
18 & Jawa Barat & 17.24 & Riau & 12.07
\end{tabular}




\begin{tabular}{|c|c|c|c|c|}
\hline Peringkat & Nama Pemprov & Tanpa & Nama Pemda & Dengan \\
\hline 19 & Nusa Tenggara Barat & 17.24 & Bengkulu & 12.07 \\
\hline 20 & Sumatera Utara & 13.79 & Jambi & 10.34 \\
\hline 21 & Jambi & 13.79 & Lampung & 8.62 \\
\hline 22 & Lampung & 13.79 & Kalimantan Utara & 8.62 \\
\hline 23 & Kalimantan Utara & 13.79 & Sulawesi Tengah & 8.62 \\
\hline 24 & Sulawesi Tengah & 13.79 & Maluku & 8.62 \\
\hline 25 & Maluku & 13.79 & Sumatera Utara & 6.90 \\
\hline 26 & Bangka Belitung & 10.34 & Bangka Belitung & 6.90 \\
\hline 27 & Sulawesi Selatan & 10.34 & Sulawesi Selatan & 6.90 \\
\hline 28 & Papua & 10.34 & Papua & 6.90 \\
\hline 29 & Kepulauan Riau & 6.90 & Kepulauan Riau & 5.17 \\
\hline 30 & Sulawesi Utara & 6.90 & Sulawesi Utara & 5.17 \\
\hline 31 & Sulawesi Tenggara & 3.45 & Sulawesi Tenggara & 3.45 \\
\hline 32 & Sulawesi Barat & 3.45 & Sulawesi Barat & 3.45 \\
\hline 33 & Maluku Utara & 3.45 & Maluku Utara & 3.45 \\
\hline \multirow[t]{2}{*}{34} & Papua Barat & 3.45 & Papua Barat & 3.45 \\
\hline & Rata-rata & 23.73 & Rata-rata & 16.84 \\
\hline
\end{tabular}

Merujuk pada IBP (2015) tentang kualitas keterbukaan, dapat disimpulkan bahwa seluruh pemprov yang diamati dalam penelitian ini tergolong dalam kualifikasi keterbukaan anggaran tidak cukup (insufficient). Terdapat tiga pemprov dalam kualifikasi transparansi terbatas (limited), tujuh pemprov termasuk dalam kualifikasi transparansi minimal (minimal), dan dua puluh empat pemprov tergolong dalam kualifikasi transparansi sedikit (scant or none). Lebih jelasnya dapat dilihat pada Tabel 7.

Tabel 7. Hasil Tingkat Kategori Keterbukaan Informasi Anggaran

\begin{tabular}{|c|c|c|c|c|c|}
\hline \multirow[b]{2}{*}{$\begin{array}{c}\text { Kategori } \\
\text { Skor }\end{array}$} & \multicolumn{3}{|c|}{ Tidak cukup (insufficient) } & \multicolumn{2}{|c|}{ Cukup (sufficient) } \\
\hline & $\begin{array}{c}\text { Sedikit } \\
0-20\end{array}$ & $\begin{array}{c}\text { Minimal } \\
21-40\end{array}$ & $\begin{array}{c}\text { Terbatas } \\
41-60\end{array}$ & $\begin{array}{c}\text { Substansial } \\
\quad 61-80\end{array}$ & $\begin{array}{c}\text { Ekstensif } \\
81-100\end{array}$ \\
\hline $\begin{array}{l}\text { Nama } \\
\text { Pemprov }\end{array}$ & $\begin{array}{l}\text { Aceh, } \\
\text { Bali, } \\
\text { Kalimantan Selatan, } \\
\text { Jawa Barat, } \\
\text { Kalimantan Barat, } \\
\text { Nusa Tenggara Barat, } \\
\text { Nusa Tenggara Timur, } \\
\text { Riau, } \\
\text { Bengkulu, } \\
\text { Jambi, } \\
\text { Lampung, } \\
\text { Kalimatan Utara, } \\
\text { Sulawesi Tengah, } \\
\text { Maluku, } \\
\text { Sumatera Utara, } \\
\text { Bangka Belitung, } \\
\text { Sulawesi Selatan, } \\
\text { Papua, } \\
\text { Kepulauan Riau, } \\
\text { Sulawesi Utara, } \\
\text { Sulawesi Tenggara, } \\
\text { Sulawesi Barat, } \\
\text { Maluku Utara, dan } \\
\text { Papua Barat }\end{array}$ & $\begin{array}{l}\text { Sumatera Selatan, } \\
\text { Banten, } \\
\text { DKI Jakarta, } \\
\text { Jawa Timur, } \\
\text { Gorontalo, } \\
\text { Sumatera Barat, dan } \\
\text { D.I. Yogyakarta }\end{array}$ & $\begin{array}{l}\text { Jawa Tengah, } \\
\text { Kalimantan Tengah, } \\
\text { dan } \\
\text { Kalimantan Timur }\end{array}$ & - & - \\
\hline
\end{tabular}

Berdasarkan pada Tabel 7, dapat disimpulkan bahwa secara keseluruhan pemprov masih berada dalam kualifikasi transparansi tidak cukup (insufficient). Hal ini mengindikasikan bahwa pemprov masih menganggap dokumen (data) pengelolaan keuangan daerah masih bersifat rahasia, sehingga tidak dipublikasikan untuk umum (publik). 


\section{Simpulan}

Hasil penelitian ini menunjukkan bahwa rata-rata tingkat transparansi pengelolaan daerah masih sangat sedikit (rendah), yakni sebesar 16,84\%. Pemprov dengan peringkat tertinggi adalah Pemprov Jawa Tengah dengan indeks sebesar 50\% dan yang terendah adalah Pemprov Sulawesi Tenggara, Pemprov Sulawesi Barat, Pemprov Maluku Utara, dan Pemprov Papua Barat dengan indeks transparansi pengelolaan keuangan daerah yang masingmasing sebesar 3,45\%.

Kontribusi penelitian ini memberikan sumber informasi tambahan dalam pengambilan keputusan yang efektif terkait dengan upaya peningkatan transparansi pengelolaan keuangan daerah di masa mendatang. Penelitian ini menunjukkan bahwa dengan memasukkan kriteria ketepatan waktu dalam mengukur transparansi pengelolaan keuangan daerah menjadikan pengukuran yang lebih akurat.

\section{Keterbatasan dan Saran untuk Penelitian Selanjutnya}

Penelitian ini juga menghadapi beberapa kendala dalam pengukuran ketepatan waktu publikasi. Hal ini dikarenakan tidak semua pemprov mencantumkan tanggal publikasi pada saat mengunggah informasi pengelolaan keuagan daerah. Namun, hal tersebut dapat dilihat melalui properti dokumen dari file yang di unggah. Ternyata, terdapat pula beberapa file yang juga tidak tercantum tanggal modifikasinya. Oleh karena itu, ada beberapa informasi yang peneliti anggap tidak tepat waktu karena tidak terlihat waktu atau kapan pengunggahan informasi pengelolaan keuangan daerah tersebut dilakukan. Penelitian selanjutnya diharapkan dapat mengukur tingkat transparansi pengelolaan keuangan daerah dengan menggunakan pemerintah kabupaten dan kota sebagai objek penelitiannya.

\section{Daftar Referensi}

Armstrong, E. 2005. Integrity, transparency and accountability in public administration: recent trends, regional and international developments and emerging issues. United Nations, Department of Economic and Social.

Chalid, P. 2005. Keuangan daerah, investasi, dan desentralisasi. Jakarta: Kemitraan.

de Araujo, J. F. F. E., dan F. Tejedo-Romero. 2016. Local government transparency index: determinants of municipalities' rankings. International Journal of Public Sector Management 29 (4): 327-347.

Fung, B. 2014. The demand and need for transparency and disclosure in corporate governance. Universal Journal of Management 2 (2): 72-80.

Grimmelikhuijsen, S. 2012. Linking transparency, knowledge and citizen trust in government: an experiment. International Review of Administrative Sciences 78 (1): 50-73.

Hermana, B., A. Tarigan, H. Medyawati, dan W. Silfianti. 2012. E-government implementation in Indonesia: financial transparency on the web. 3rd - International Conference on E-Education, E-Business, EManagement and E-Learning IPEDR 27: 194-199.

Hirsch, W., dan E. Osborne. 2000. Privatization of government services: pressure-group resistance and service transparency. Journal of Labor Research XXI (2): 315-326.

Huwae, K. 2016. Analisis tingkat keterbukaan informasi pengelolaan keuangan daerah (studi di provinsi Daerah Istimewa Yogyakarta). Universitas Gadjah Mada.

IBP. 2015. Open budget survey 2015. Diakses dari http://www.internationalbudget.org/wpcontent/uploads/OBS2015-Executive-Summary-English.pdf

Mardiasmo. 2002. Akuntansi sektor publik. Yogyakarta: Andi. 2004. Otonomi dan manajemen keuangan daerah. Yogyakarta: Andi.

Martani, D., D. Fitriasari, dan Annisa. 2014. Financial and performance transparency on the local government websites in Indonesia. Journal of Theoretical and Applied Information Technology 60 (3): 504-516.

Meijer, A. 2013. Understanding the complex dynamics of transparency. Public Administration Review 73 (3): 429-439.

Ridha, M. A., dan H. Basuki. 2012. Pengaruh tekanan eksternal, ketidakpastian lingkungan, dan komitmen 
managemen terhadap penerapan transparansi pelaporan keuangan. Universitas Gajah Mada.

Silver, D. 2005. Creating transparency for public companies: The convergence of PR and IR in the Post-SarbanesOxley marketplace. The Public Relations Strategist 11 (1): 14-17

Sofia, A., dan B. Husen. 2013. Analisis Transparansi Dan Akuntabilitas Pemerintah Daerah Melalui Pengungkapan Informasi Pada Website. Jurnal Manajemen Indonesia 12: 297-308.

Undang-Undang Republik Indonesia Nomor 14 tahun 2008 tentang Keterbukaan Informasi Publik. 


\section{Lampiran:}

Lampiran 1. Indikator Penetapan Ketepatan Waktu Pengungkapan*

\begin{tabular}{|c|c|c|c|}
\hline Rincian Indikator & $\begin{array}{l}\text { Waktu Penetapan } \\
\text { Permendagri } \\
\text { No } 13 / 2006 \\
\end{array}$ & $\begin{array}{l}\text { Pemerintah } \\
\text { Daerah }\end{array}$ & $\begin{array}{l}\text { Batas Akhir } \\
\text { Unggah** }\end{array}$ \\
\hline \multicolumn{4}{|l|}{ Tahap Perencanaan: } \\
\hline Ringkasan Dokumen RKPD & Akhir Mei & $\begin{array}{c}\text { Tanggal } \\
\text { penetapan }\end{array}$ & $\begin{array}{l}30 \text { hari setelah } \\
\text { penetapan }\end{array}$ \\
\hline Kebijakan Umum Anggaran & Minggu ke-1 Juli & $\begin{array}{l}\text { Tanggal } \\
\text { penetapan }\end{array}$ & $\begin{array}{l}30 \text { hari setelah } \\
\text { penetapan }\end{array}$ \\
\hline $\begin{array}{l}\text { Ringkasan Dokumen Prioritas dan Plafon } \\
\text { Anggaran }\end{array}$ & Akhir Juli & $\begin{array}{l}\text { Tanggal } \\
\text { penetapan }\end{array}$ & $\begin{array}{l}30 \text { hari setelah } \\
\text { penetapan }\end{array}$ \\
\hline Ringkasan Dokumen RKA-SKPD & Minggu Ke-2 September & $\begin{array}{l}\text { Tanggal } \\
\text { penetapan }\end{array}$ & $\begin{array}{l}30 \text { hari setelah } \\
\text { penetapan }\end{array}$ \\
\hline Ringkasan Dokumen RKA-PPKD & Minggu Ke-2 September & $\begin{array}{l}\text { Tanggal } \\
\text { penetapan }\end{array}$ & $\begin{array}{l}30 \text { hari setelah } \\
\text { penetapan }\end{array}$ \\
\hline $\begin{array}{l}\text { Ringkasan Dokumen Rancangan Peraturan } \\
\text { Daerah tentang APBD }\end{array}$ & Akhir November & $\begin{array}{l}\text { Tanggal } \\
\text { penetapan }\end{array}$ & $\begin{array}{l}30 \text { hari setelah } \\
\text { penetapan }\end{array}$ \\
\hline Peraturan Daerah tentang APBD & Paling lambat akhir Desember & $\begin{array}{l}\text { Tanggal } \\
\text { penetapan }\end{array}$ & $\begin{array}{l}30 \text { hari setelah } \\
\text { penetapan }\end{array}$ \\
\hline $\begin{array}{l}\text { Peraturan Kepala Daerah tentang } \\
\text { Penjabaran APBD }\end{array}$ & Paling lambat akhir Desember & $\begin{array}{l}\text { Tanggal } \\
\text { penetapan }\end{array}$ & $\begin{array}{l}30 \text { hari setelah } \\
\text { penetapan }\end{array}$ \\
\hline Ringkasan DPA SKPD & 15 hari kerja setelah penetapan APBD & $\begin{array}{l}\text { Tanggal } \\
\text { penetapan }\end{array}$ & $\begin{array}{l}30 \text { hari setelah } \\
\text { penetapan }\end{array}$ \\
\hline DPA PPKD & 15 hari kerja setelah penetapan APBD & $\begin{array}{l}\text { Tanggal } \\
\text { penetapan }\end{array}$ & $\begin{array}{l}30 \text { hari setelah } \\
\text { penetapan }\end{array}$ \\
\hline \multicolumn{4}{|l|}{ Tahap Pelaksanaan: } \\
\hline Realisasi Pendapatan Daerah & $\begin{array}{l}\text { Minggu Ke-2 Juli tahun anggaran berkenaan } \\
\text { (S.I) }\end{array}$ & $\begin{array}{c}\text { Tanggal } \\
\text { penetapan }\end{array}$ & $\begin{array}{l}30 \text { hari setelah } \\
\text { penetapan/ online }\end{array}$ \\
\hline Realisasi Belanja Daerah & $\begin{array}{l}\text { Minggu Ke-2 Juli tahun anggaran berkenaan } \\
\text { (S.I) }\end{array}$ & $\begin{array}{l}\text { Tanggal } \\
\text { penetapan }\end{array}$ & $\begin{array}{l}30 \text { hari setelah } \\
\text { penetapan/ online }\end{array}$ \\
\hline Realisasi Pembiayaan Daerah & $\begin{array}{c}\text { Minggu Ke-2 Juli tahun anggaran berkenaan } \\
\text { (S.I) }\end{array}$ & $\begin{array}{l}\text { Tanggal } \\
\text { penetapan }\end{array}$ & $\begin{array}{l}30 \text { hari setelah } \\
\text { penetapan/ online }\end{array}$ \\
\hline $\begin{array}{l}\text { Ringkasan Dokumen Rancangan Perubahan } \\
\text { APBD }\end{array}$ & Minggu ke-1 Agustus tahun anggaran berjalan & $\begin{array}{l}\text { Tanggal } \\
\text { penetapan }\end{array}$ & $\begin{array}{l}30 \text { hari setelah } \\
\text { penetapan }\end{array}$ \\
\hline Peraturan Daerah tentang Perubahan APBD & Akhir September tahun anggaran berjalan & $\begin{array}{l}\text { Tanggal } \\
\text { penetapan }\end{array}$ & $\begin{array}{l}30 \text { hari setelah } \\
\text { penetapan }\end{array}$ \\
\hline $\begin{array}{l}\text { Peraturan Kepala Daerah tentang } \\
\text { Penjabaran Perubahan APBD }\end{array}$ & Akhir September tahun anggaran berjalan & $\begin{array}{l}\text { Tanggal } \\
\text { penetapan }\end{array}$ & $\begin{array}{l}30 \text { hari setelah } \\
\text { penetapan }\end{array}$ \\
\hline Ringkasan RKA Perubahan APBD & Minggu ke-3 Agustus tahun anggaran berjalan & $\begin{array}{l}\text { Tanggal } \\
\text { penetapan }\end{array}$ & $\begin{array}{l}30 \text { hari setelah } \\
\text { penetapan }\end{array}$ \\
\hline Rencana Umum Pengadaan & & $\begin{array}{c}\text { Sistem } \\
\text { elektronik }\end{array}$ & Selalu di-perbaharui \\
\hline $\begin{array}{l}\text { SK Kepala Daerah tentang Pejabat } \\
\text { Pengelola Keuangan Daerah } \\
\text { Tahap Pelaporan dan Pertanggungjawaban: }\end{array}$ & Tanggal penetapan & $\begin{array}{l}\text { Tanggal } \\
\text { penetapan }\end{array}$ & $\begin{array}{l}30 \text { hari setelah } \\
\text { penetapan }\end{array}$ \\
\hline $\begin{array}{l}\text { Peraturan Kepala Daerah tentang Kebijakan } \\
\text { Akuntansi }\end{array}$ & Tanggal penetapan & $\begin{array}{c}\text { Tanggal } \\
\text { penetapan }\end{array}$ & $\begin{array}{l}30 \text { hari setelah } \\
\text { penetapan }\end{array}$ \\
\hline Laporan Arus Kas & 6 bulan setelah tahun anggaran berakhir & $\begin{array}{l}\text { Tanggal } \\
\text { penetapan }\end{array}$ & $\begin{array}{l}30 \text { hari setelah } \\
\text { penetapan }\end{array}$ \\
\hline Laporan Realisasi Anggaran Seluruh SKPD & 6 bulan setelah tahun anggaran berakhir & $\begin{array}{l}\text { Tanggal } \\
\text { penetapan }\end{array}$ & $\begin{array}{l}30 \text { hari setelah } \\
\text { penetapan }\end{array}$ \\
\hline Laporan Realisasi Anggaran PPKD & 6 bulan setelah tahun anggaran berakhir & $\begin{array}{l}\text { Tanggal } \\
\text { penetapan }\end{array}$ & $\begin{array}{l}30 \text { hari setelah } \\
\text { penetapan }\end{array}$ \\
\hline Neraca & 6 bulan setelah tahun anggaran berakhir & $\begin{array}{l}\text { Tanggal } \\
\text { penetapan }\end{array}$ & $\begin{array}{l}30 \text { hari setelah } \\
\text { penetapan }\end{array}$ \\
\hline CaLK Pemerintah Daerah & 6 bulan setelah tahun anggaran berakhir & $\begin{array}{l}\text { Tanggal } \\
\text { penetapan }\end{array}$ & $\begin{array}{l}30 \text { hari setelah } \\
\text { penetapan }\end{array}$ \\
\hline $\begin{array}{l}\text { Laporan Keuangan BUMD/Perusahaan } \\
\text { Daerah }\end{array}$ & 6 bulan setelah tahun anggaran berakhir & $\begin{array}{l}\text { Tanggal } \\
\text { penetapan }\end{array}$ & $\begin{array}{l}30 \text { hari setelah } \\
\text { penetapan }\end{array}$ \\
\hline $\begin{array}{l}\text { Laporan Akuntabilitas dan Kinerja Tahunan } \\
\text { Pemerintah Daerah }\end{array}$ & $\begin{array}{c}31 \text { Maret } \\
\text { (3 bulan setelah tahun anggaran) }\end{array}$ & Tanggal & 30 hari setelah \\
\hline $\begin{array}{l}\text { Penetapan Perda Pertanggungjawaban } \\
\text { Pelaksanaan APBD }\end{array}$ & 6 bulan setelah tahun anggaran berakhir & $\begin{array}{l}\text { penetapan } \\
\text { Tanggal } \\
\text { penetapan }\end{array}$ & $\begin{array}{l}\text { penetapan } \\
30 \text { hari setelah } \\
\text { penetapan }\end{array}$ \\
\hline Opini BPK RI & 6 bulan setelah tahun anggaran berakhir & $\begin{array}{c}\text { Tanggal } \\
\text { penetapan }\end{array}$ & $\begin{array}{l}30 \text { hari setelah } \\
\text { penetapan }\end{array}$ \\
\hline
\end{tabular}

*Nilai ketepatan waktu informasi transparansi pengelolaan keuangan daerah diperoleh dari waktu (tanggal dan bulan) penetapan dibandingkan dengan waktu unggah dokumen. Apabila tanggal unggah melebihi tanggal atau rentang waktu yang dipersyaratkan (batas akhir unggah), yaitu 30 hari. Maka, dikatakan tidak tepat waktu dan diberi nilai nol. Sebaliknya, jika publikasi (unggah dokumen) berada pada rentang waktu yang 
dipersyaratkan, maka akan diberi nilai 1.** Penentuan batas akhir unggah, yakni selama 30 hari didasarkan pada rentang waktu dari setiap tahap pengelolaan keuangan daerah memiliki rentang waktu kurang lebih 30 hari. Misalnya, penyusunan RKPD ditetapkan paling lambat setiap akhir Mei. Sementara itu, untuk penetapan KUA dan PPAS dilakukan paling lambat bulan Juli (lihat, Permendagri No. 13 Tahun 2006).

Lampiran 2. Rincian Indikator Tahapan Pengelolaan Keuangan Daerah

\begin{tabular}{|c|c|c|}
\hline Tahapan & Rincian Indikator & Tahun \\
\hline \multirow{11}{*}{ Perencanaan } & 1. Ringkasan Dokumen RKPD & 2016 \\
\hline & Kebijakan Umum Anggaran & 2016 \\
\hline & Ringkasan Dokumen Prioritas dan Plafon Anggaran & 2016 \\
\hline & Ringkasan Dokumen RKA-SKPD & 2016 \\
\hline & Ringkasan Dokumen RKA-PPKD & 2016 \\
\hline & Ringkasan Dokumen Rancangan Peraturan Daerah tentang APBD & 2016 \\
\hline & Peraturan Daerah tentang APBD & 2016 \\
\hline & Peraturan Kepala Daerah tentang Penjabaran APBD & 2016 \\
\hline & Ringkasan DPA SKPD & 2016 \\
\hline & 10. DPA PPKD & 2016 \\
\hline & Realisasi Pendapatan Daerah & 2016 \\
\hline \multirow{7}{*}{ Pelaksanaan } & Realisasi Belanja Daerah & 2016 \\
\hline & Realisasi Pembiayaan Daerah & 2016 \\
\hline & Ringkasan Dokumen Rancangan Perubahan APBD & 2016 \\
\hline & Peraturan Daerah tentang Perubahan APBD & 2016 \\
\hline & Peraturan Kepala Daerah tentang Penjabaran Perubahan APBD & 2016 \\
\hline & Ringkasan RKA Perubahan APBD & 2016 \\
\hline & Rencana Umum Pengadaan & 2016 \\
\hline \multirow{11}{*}{$\begin{array}{l}\text { Pelaporan dan } \\
\text { Pertanggung- } \\
\text { jawaban }\end{array}$} & SK Kepala Daerah tentang Pejabat Pengelola Keuangan Daerah & 2016 \\
\hline & 1. Peraturan Kepala Daerah tentang Kebijakan Akuntansi & 2016 \\
\hline & 2. Laporan Arus Kas & 2015 \\
\hline & 3. Laporan Realisasi Anggaran Seluruh SKPD & 2015 \\
\hline & 4. Laporan Realisasi Anggaran PPKD & 2015 \\
\hline & 5. Neraca & 2015 \\
\hline & 6. CaLK Pemerintah Daerah & 2015 \\
\hline & 7. Laporan Keuangan BUMD/Perusahaan Daerah & 2015 \\
\hline & Laporan Akuntabilitas dan Kinerja Tahunan Pemerintah Daerah & 2015 \\
\hline & Penetapan Perda Pertanggungjawaban Pelaksanaan APBD & 2015 \\
\hline & 10. Opini BPK RI & 2015 \\
\hline
\end{tabular}

Instrumen: Diadaptasi dari penelitian Huwae (2016)

Lampiran 3. Daftar Website Pemprov

\begin{tabular}{|c|c|c|}
\hline No. & Nama Pemprov & Website Resmi \\
\hline 1. & Aceh & www.acehprov.go.id \\
\hline 2. & Sumatera Utara & www.sumutprov.go.id \\
\hline 3. & Sumatera Barat & www.sumbarprov.go.id \\
\hline 4. & Riau & www.riauprov.go.id \\
\hline 5. & Jambi & www.jambiprov.go.id \\
\hline 6. & Sumatera Selatan & WwW.sumselprov.go.id \\
\hline 7. & Bengkulu & www.bengkuluprov.go.id \\
\hline 8. & Lampung & www.lampungprov.go.id \\
\hline 9. & Kepulauan Bangka Belitung & www.banbelprov.go.id \\
\hline 10. & Kepulauan Riau & www.kepriprov.go.id \\
\hline 11. & DKI Jakarta & www.jakartaprov.go.id \\
\hline 12. & Jawa Barat & www.jabarprov.go.id \\
\hline 13. & Jawa Tengah & www.jatengprov.go.id \\
\hline 14. & D.I. Yogyakarta & www.jogjaprov.go.id \\
\hline 15. & Jawa Timur & www.jatimprov.go.id \\
\hline 16. & Banten & www.bantenprov.go.id \\
\hline 17. & Bali & www.baliprov.go.id \\
\hline
\end{tabular}

\begin{tabular}{|c|c|c|}
\hline No. & Nama Pemprov & Website Resmi \\
\hline 18. & Nusa Tenggara Barat & www.ntbprov.go.id \\
\hline 19. & Nusa Tenggara Timur & www.nttprov.go.id \\
\hline 20. & Kalimantan Barat & www.kalbarprov.go.id \\
\hline 21. & Kalimantan Tengah & www.kaltengprov.go.id \\
\hline 22. & Kalimantan Selatan & www.kalselprov.go.id \\
\hline 23. & Kalimantan Timur & www.kaltimprov.go.id \\
\hline 24. & Kalimantan Utara & www.kaltaraprov.go.di \\
\hline 25. & Sulawesi Utara & www.sulutprov.go.id \\
\hline 26. & Sulawesi Tengah & www.sultengprov.go.id \\
\hline 27. & Sulawesi Selatan & WwW.sulselprov.go.id \\
\hline 28. & Sulawesi Tenggara & WwW.sulawesitenggaraprov.go.id \\
\hline 29. & Gorontalo & www.gorontaloprov.go.id \\
\hline 30. & Sulawesi Barat & www.sulbarprov.go.id \\
\hline 31. & Maluku & www.malukuprov.go.id \\
\hline 32. & Maluku Utara & www.malutprov.go.id \\
\hline 33. & Papua & www.papuaprov.go.id \\
\hline 34 & Papua Barat & www.papuabaratprov.go.id \\
\hline
\end{tabular}


Lampiran 3. Contoh Format Penilaian Transparansi Pengelolaan Keuangan Daerah

\begin{tabular}{|c|c|c|c|c|c|c|c|c|c|}
\hline \multicolumn{10}{|c|}{ 13. Provinsi Jawa Tengah } \\
\hline \multirow[t]{3}{*}{ Indikator } & \multicolumn{9}{|c|}{ Kriteria } \\
\hline & $\begin{array}{l}\text { Tepat Waktu } \\
\text { Tanggal } \\
\text { Penetapan }\end{array}$ & $\begin{array}{l}\text { Tanggal } \\
\text { Unggah }\end{array}$ & $\mathrm{RW}^{*}$ & BAU* & S/TS* & Nilai & Tersedia & $\begin{array}{c}\text { Dapat } \\
\text { Diakses }\end{array}$ & Jumlah \\
\hline & 1 & 2 & 3 & 4 & 5 & 6 & 7 & 8 & 9 \\
\hline 1 & $5 / 31 / 2015$ & $6 / 7 / 2016$ & $>360$ & 30 & TS & 0 & 1 & 1 & 0.5 \\
\hline 2 & & & & & & 0 & 0 & 0 & 0 \\
\hline 3 & & & & & & 0 & 0 & 0 & 0 \\
\hline 4 & & & & & & 0 & 0 & 0 & 0 \\
\hline 5 & & & & & & 0 & 0 & 0 & 0 \\
\hline 6 & $12 / 25 / 2015$ & $1 / 25 / 2016$ & 30 & 30 & $\mathrm{~S}$ & 1 & 1 & 1 & 1 \\
\hline 7 & $12 / 25 / 2015$ & $1 / 26 / 2016$ & 30 & 30 & $\mathrm{~S}$ & 1 & 1 & 1 & 1 \\
\hline 8 & $12 / 25 / 2015$ & $1 / 25 / 2016$ & 30 & 30 & S & 1 & 1 & 1 & 1 \\
\hline 9 & $12 / 25 / 2015$ & $1 / 25 / 2016$ & 30 & 30 & $\mathrm{~S}$ & 1 & 1 & 1 & 1 \\
\hline 10 & $12 / 25 / 2015$ & $1 / 25 / 2016$ & 30 & 30 & $\mathrm{~S}$ & 1 & 1 & 1 & 1 \\
\hline 11 & online & Update & 30 & 30 & $\mathrm{~S}$ & 1 & 1 & 1 & 1 \\
\hline 12 & online & Update & 30 & 30 & $\mathrm{~S}$ & 1 & 1 & 1 & 1 \\
\hline 13 & & & & & & 0 & 0 & 0 & 0 \\
\hline 14 & $11 / 1 / 2016$ & $11 / 4 / 2016$ & 3 & 30 & $\mathrm{~S}$ & 1 & 1 & 1 & 1 \\
\hline 15 & $11 / 1 / 2016$ & $11 / 4 / 2016$ & 3 & 30 & S & 1 & 1 & 1 & 1 \\
\hline 16 & $11 / 1 / 2016$ & $11 / 4 / 2016$ & 3 & 30 & $\mathrm{~S}$ & 1 & 1 & 1 & 1 \\
\hline 17 & & & & & & 0 & 0 & 0 & 0 \\
\hline 18 & LPSE & Update & 30 & 30 & $\mathrm{~S}$ & 1 & 1 & 1 & 1 \\
\hline 19 & & & & & & 0 & 0 & 0 & 0 \\
\hline 20 & $7 / 17 / 2016$ & 9/9/2016 & 56 & 30 & TS & 0 & 1 & 1 & 0.5 \\
\hline 21 & $7 / 17 / 2016$ & 9/9/2016 & 56 & 30 & TS & 0 & 1 & 1 & 0.5 \\
\hline 22 & 7/17/2016 & 9/9/2016 & 56 & 30 & TS & 0 & 1 & 1 & 0.5 \\
\hline 23 & $7 / 17 / 2016$ & 9/9/2016 & 56 & 30 & TS & 0 & 1 & 1 & 0.5 \\
\hline 24 & $7 / 17 / 2016$ & 9/9/2016 & 56 & 30 & TS & 0 & 1 & 1 & 0.5 \\
\hline 25 & 7/17/2016 & 9/9/2016 & 56 & 30 & TS & 0 & 1 & 1 & 0.5 \\
\hline 26 & & & & & & 0 & 0 & 0 & 0 \\
\hline 27 & & & & & & 0 & 0 & 0 & 0 \\
\hline 28 & & & & & & 0 & 0 & 0 & 0 \\
\hline 29 & & & & & & 0 & 0 & 0 & 0 \\
\hline Total & & & & & & 11 & 18 & 18 & 14.5 \\
\hline Indeks & & & & & & & & & 50.00 \\
\hline
\end{tabular}

Keterangan:

RW* Rentang Waktu, BAU* Batas Akhir Unggah, S/TS* Sesuai/Tidak sesuai, Jumlah didapatkan dari (kolom $6 * 0,5)+(($ Kolom $7 * 0,25)+($ Kolom $8 * 0,25))$.

Nilai Indeks, diperoleh dari nilai total dibagi nilai yang diharapkan (29), selanjutnya dikalikan dengan 100. 